\title{
Concepções de Professores da Rede Pública de Pernambuco sobre Feiras de Ciências: Reflexões a partir de uma Atividade Lúdica
}

\author{
Simão Dias de Vasconcelos Filho*, Kênio Erithon Cavalcante Lima**
}

\section{Resumo}

Este artigo apresenta um relato de experiência construída a partir de uma formação continuada sobre Feiras de Ciências, direcionada a professores de escolas públicas de Pernambuco. A pesquisa foi elaborada na forma de uma observação participante, e teve como instrumentação uma atividade lúdica coletiva, com o objetivo de examinar as concepções dos professores de redes municipais sobre Feiras de Ciências. No total, 210 professores de oito municípios participaram espontaneamente da formação. Por meio das discussões em torno de questionamentos divergentes presentes na dinâmica de grupo "Viagem Científica", buscamos compreender as concepções sobre o planejamento, organização, acompanhamento e avaliação de projetos de feiras de ciências. Observamos que a maioria dos professores prioriza uma avaliação das Feiras baseada no processo de construção dos projetos e defende um monitoramento constante do progresso dos estudantes mesmo que isso comprometa parcialmente a autonomia dos participantes. Identificamos divergências nas concepções dos professores quanto ao seu papel como orientadores especialistas nos assuntos abordados nas feiras e também sobre os critérios para a escolha dos temas dos projetos - se seriam priorizados problemas locais ou de natureza mais geral. O estudo contribui ainda para contextualizar estas concepções sob a ótica do ensino por investigação.

Palavras-chave: Ensino fundamental. Formação continuada. Dinâmica de grupo. Educação pública. Ensino por investigação.

\footnotetext{
PhD em Zoologia pela University of Oxford. Professor Titular do Departamento de Zoologia da Universidade Federal de Pernambuco. Professor do Mestrado Profissional em Ensino de Biologia e do Programa de Pós-Graduação em Biologia Animal (UFPE). Coordenador do Grupo de Pesquisa Ensino de Biologia. Brasil. E-mail: simao.vasconcelosfo@ufpe.br

* Doutor em Educação pela Universidade Federal de Pernambuco. Professor Adjunto II do Núcleo de Ciências Biológicas do Centro Acadêmico de Vitória da Universidade Federal de Pernambuco (UFPE). Coordenador do Mestrado Profissional em Ensino de Biologia (PROFBIO) da Associada UFPE e Professor no Programa de Pós-Graduação em Educação (UFPE). Brasil. E-mail: kenio.lima@ufpe.br
} 


\section{Introdução}

\section{A formação continuada como oportunidade para reflexão da prática docente}

Um dos aspectos mais delicados e complexos na formação continuada de professores refere-se à compreensão e valorização, pelo formador, das concepções dos participantes sobre ensino e aprendizagem. Tais momentos podem ser comprometidos por uma miríade de dificuldades que variam desde a fraca motivação para participar dos encontros - cuja presença frequentemente é obrigatória - à resistência inicial a mais uma "capacitação" dentre tantas às quais rotineiramente são convocados, além da desconfiança em relação aos frutos dessa iniciativa. Somam-se a este cenário o cansaço de uma jornada extenuante de trabalho, a dificuldade em explicitar posicionamentos e limitações diante dos pares e até mesmo a sensação de intimidação diante dos mediadores. Ao final, o resultado de iniciativas bem-intencionadas de atualização pedagógica pode variar do enriquecedor ao desastroso.

Momentos de formação continuada contribuem para reduzir lacunas na formação teórico-prática de professores de Ciências, oferecendo-lhes oportunidades de (re)pensar a prática docente (TARDIF, 2000; ARAÚJO; ARAÚJO; SILVA, 2015). Da mesma forma, permitem que o conhecimento científico historicamente construído seja ressignificado, atualizando a relação do professor com os saberes necessários para elaborar a construção de conhecimentos junto a seus estudantes. Nessa compreensão,

Os profissionais devem, assim, autoformar-se e reciclar-se através de diferentes meios, após seus estudos universitários iniciais. Desse ponto de vista, a formação profissional ocupa, em princípio, uma boa parte da carreira e os conhecimentos profissionais partilham com os conhecimentos científicos e técnicos a propriedade de serem revisáveis, criticáveis e passíveis de aperfeiçoamento (TARDIF, 2000, p. 7).

A formação continuada propicia ao professor refletir sobre sua atuação e as trocas de conhecimento com seus pares e com os estudantes, autoformando e se autoconhecendo em um fluxo contínuo de saberes (ARAÚJO; ARAÚJO; SILVA, 2015). Nessa renovação do modo de se entender professor, o docente é um sujeito social que possui uma história de vida atrelada ao conjunto de saberes teóricos e práticos que moldam sua atuação profissional. Falamos de um ser que é "um ator 
social, tem emoções, um corpo, poderes, uma personalidade, uma cultura, ou mesmo culturas, e seus pensamentos e ações carregam as marcas dos contextos nos quais se inserem" (TARDIF, 2000, p. 15). Como sujeito, o docente apropria-se de um conjunto de saberes e valores ao longo de sua profissionalização, os quais serão exigidos em sua atuação; ou seja, o profissional necessitará inovar e aperfeiçoar-se continuamente para então oportunizar as situações de ensino.

Para Silva \& Pacca (2011), a formação continuada coletiva favorece a narrativa e a negociação, e contribui para o exercício da cidadania e para a construção da autonomia. Trata-se de uma oportunidade de resgatar concepções dos professores para reestruturar, coletivamente, possibilidades de ensino para intervir com seus estudantes, fortalecendo aspectos motivacionais e reflexivos referentes à prática didático-metodológica.

Ações de formação continuada, entretanto, precisam adequar-se ao nível de conhecimento e envolvimento dos professores com a metodologia de ensino utilizada, suas experiências, seus valores e atitudes. A construção dessas ações demanda iniciativas que ajudem a compreender a visão do professor sobre estratégias para superar o ensino tradicional e conteudista, ou seja, como o professor constrói situações que desenvolvam o espírito investigativo do estudante, problematizando as situações didáticas para melhor envolvê-lo no processo da investigação (ZÔMPERO; LABURÚ, 2011; SASSERON, 2015).

A formação continuada do professor de Ciências situa-se em um paradoxo: ao mesmo tempo em que se exige um repertório de estratégias didáticas que priorizam a autonomia, o senso investigativo, a criatividade e o protagonismo do estudante, percebemos, em nosso campo de atuação, que as formações continuadas frequentemente ofertadas pelos sistemas de ensino adotam formatos rígidos, centrados no protagonismo do mediador. Formatos tradicionais, como conferências esporádicas, podem ter eficiência limitada em provocar mudanças no professor (OPFER; PEDDER, 2011, p. 384). Este posicionamento permeia nossa visão de formação continuada não apenas como um momento de "atualização" de conteúdos, mas também como uma reflexão do professor sobre sua prática docente, para que ele se perceba protagonista, crítico e reflexivo. Este desafio faz-se particularmente pertinente nas oportunidades para incorporar na prática docente o ensino por investigação (NASCIMENTO; GOMES, 2018). Um exemplo de atividade prática que historicamente tem potencial para apropriar elementos do ensino por investigação consiste nas 
Feiras de Ciências, as quais, em nossa percepção, tem sido pouco explorado em ações de formação continuada.

\section{Feiras de Ciências e o ensino por investigação}

O ensino por investigação confere uma faceta transformadora às situações didáticas; afinal, é na escola que a convivência entre o conhecimento científico em construção e o conteúdo curricular oportuniza os conflitos necessários para a transformação dos saberes quando os estudantes se colocam como protagonistas e se apropriam dos processos e conhecimentos anteriormente por eles desconhecidos (MUNFORD; LIMA, 2007). Ao vivenciar esses processos os estudantes se permitem ampliar as possibilidades de conhecer e se apropriar do conhecimento, estimulando sua autonomia e a capacidade crítica, a partir de sua realidade (WERNECK, 2006).

Para Carvalho (2018), no ensino por investigação o professor cria condições para os estudantes pensarem, considerando a estrutura do conhecimento; falarem, baseados em argumentos bem construídos; lerem, entendendo criticamente o conteúdo; e escreverem, demostrando autoria nas ideias expostas. Complementamos esta visão defendendo que também acontece o fortalecimento de linguagens e apropriação de terminologias envolvidas na disseminação do conhecimento científico.

Grande parte dessas competências pode ser trabalhada em projetos de Feiras de Ciências (FC), as quais podem ser definidas como exercícios de aprendizagem que inserem o estudante na condição de agente do processo, pois possibilitam ainda apresentar os saberes então discutidos - um novo conhecimento, uma nova apropriação de saberes - em linguagem acessível e relacionados à sua realidade (FARIAS; GONÇALVES, 2011). Desta forma, criam desafios e ampliam o diálogo entre os estudantes como meio de compreender os fenômenos ao seu redor (ZÔMPERO; LABURÚ, 2011), instituindo um momento-espaço de socialização de saberes e problematização dos acontecimentos naturais e/ou sociais, construídos em processos vivenciados de forma ativa. Sob o ponto de vista dos autores deste estudo, as FC podem extrapolar o formato de mostras científicas baseadas em atualizações sobre um determinado tema (embora estas sejam válidas) para materializar-se em oportunidade de ensino por investigação.

O papel das FC tem evoluído nas últimas décadas; Reis (1968) já destacava que estas "não são demonstrações paradas. Não consistem na demonstração de 
aparelhos e cartazes, mas na apresentação de experiências ou observações bem documentadas, com a presença de seus autores, que explicam ao público aquilo que estão expondo" (p. 305). Para Reis (1968), as FC, atreladas às atividades experimentais, disseminadas nas escolas e nos Clubes de Ciências, estimularam o envolvimento mais ativo de estudantes, que passaram a vivenciar processos de elaboração de suas pesquisas orientados e acompanhados pelo professor. Neste percurso, foram vitrines para divulgar e popularizar a ciência, contribuindo para envolver estudantes da Educação Primária e Secundária de várias regiões com o que a Ciência tinha de inovador e de curioso em uma época em que se buscava desenvolver o Brasil cientificamente e tecnologicamente (LIMA; TEIXEIRA, 2018).

As FC preconizam a disseminação do conhecimento validado, no exercício do estudante em construir interpretações de sua realidade para entender e discutir problemas sociais resultantes da tecnologia e da atualidade (FARIAS; GONÇALVES, 2011), o que demanda novas apropriações por parte do professor. Ou seja, a motivação das FC busca compreender a realidade social e suas necessidades construídas como consequência do processo investigativo desenvolvido por uma pesquisa e por estudos sobre o tema, culminando com um produto que expressa o olhar do estudante para a realidade investigada.

Em nossa prática de ensino cotidiana, observamos que uma série de obstáculos conceituais e metodológicos para a realização de Feiras de Ciências ainda permeia a realidade do ensino público. Isso se deve, em parte, às limitadas oportunidades em discutir e avaliar o processo/ percurso da construção do produto das feiras definição do tema, metodologia, experimentações, obtenção de resultados, análises e elaboração das conclusões como uma preocupação central dos participantes. Relatos de observação participante indicam que, frequentemente, as feiras são construídas e avaliadas com base exclusivamente no evento final, sem considerar o processo de construção do conhecimento e das escolhas e mudanças realizadas pelos estudantes durante esse percurso para trabalhar novos saberes (VASCONCELOS; SILVA; LIMA, 2015). Sob esta percepção, o professor e o estudante ignorariam as mudanças conceituais em movimento, e não se avaliaria, de fato, como a superação de obstáculos emergidos ao longo do processo da investigação reflete-se na natureza do produto exposto.

Para que seus objetivos sejam plenamente atingidos, a dinâmica construída ao longo dos projetos de FC necessita ultrapassar a simples exibição dos resultados, já 
que esse momento de exposição em si nem sempre revela as mudanças conceituais e os conflitos envolvidos na construção do conhecimento e na maturação do espírito científico dos estudantes. Afinal, neste percurso "o ato de conhecer dá-se contra um conhecimento anterior, destruindo conhecimentos mal estabelecidos, superando o que, no próprio espírito, é obstáculo à espiritualização" (BACHELARD, 2007, p. 17).

Projetos investigativos sistematizados nas FC têm se revelado como um desencadeador de atitudes positivas em relação à(s) Ciências. Entretanto, estudos sobre as metodologias adotadas por professores da rede pública de escolas da Região Nordeste ainda são escassos, mas têm ajudado a construir um rico arcabouço das aspirações e dificuldades dos atores envolvidos (VASCONCELOS; SILVA; LIMA, 2015). Apesar destes pequenos avanços, pouco se debate sobre as concepções dos professores em referência ao planejamento, à execução e à avaliação dos projetos de Feiras de Ciências.

Pesquisas sobre a atuação docente apropriam-se de uma miríade de procedimentos metodológicos que variam desde a observação participante, o estudo de caso até o levantamento direto ("survey") dos atores envolvidos. Esta abordagem distanciada e formal possui como obstáculo a limitada espontaneidade do professor "estudado", o qual dificilmente se vê como agente de sua própria investigação (FAGUNDES, 2016). Corre-se o risco de obter resultados imprecisos, idealizados e distantes da realidade do docente.

Em nossa experiência na integração da extensão universitária com a pesquisa e o ensino por investigação, frequentemente, deparamo-nos com um desafio: como conhecer a prática do professor de Ciências de uma forma aprazível, construtiva e, especialmente, colaborativa e divertida? Ao longo deste artigo descrevemos uma análise de percepções de professores, por meio de uma atividade lúdica, desenvolvida em um curso de extensão, o que gerou um diagnóstico sobre os desafios envolvidos na promoção de Feiras de Ciências.

No contexto deste estudo, trabalhamos a ludicidade como possibilidade de ruptura de estigmas e do medo, da inibição de se falar e de expressar pensamentos e críticas, pela conquista da liberdade de se colocar no direito de se apresentar como sujeito histórico e de experiências diversas, de se permitir expressar-se profissionalmente para (re)construir seus saberes docentes em formação continuada de forma mais criativa. Lança-se, com atividades lúdicas, "um estado de ânimo, um estado de espírito que expressa um sentimento de entrega, de inteireza, de vivência plena, 
e diz respeito à realidade interna do indivíduo" (LEAL; D’ÁVILA, 2013, p. 51), o qual se coloca no estado de liberdade de expressão sem estereótipos e rigidez em suas respostas e comentários. Por certo, uma das principais funções do componente recreativo desencadeado com a ludicidade é a capacidade de auto-organização fornecida à psique, ao mesmo tempo que exige liberdade, interação e vida cotidiana (DOMINGUEZ CHAVIRA, 2005).

\section{Contextualização e objetivos da pesquisa}

Fomos motivados a compreender como a extensão universitária e a pesquisa podem se retroalimentar, no estudo de um tema de importância histórica como meio de construção e divulgação de conhecimento científico, as Feiras de Ciências. A atividade prática que subsidiou nosso estudo originou-se a partir do curso de extensão "Feiras de Ciências como Ferramentas de Ensino e Pesquisa", registrado na Pró-Reitoria de Extensão da UFPE (Proext). Este curso, oferecido gratuitamente às secretarias municipais de Educação, integrou as ações do Projeto "Cientistas na Praça: A Biodiversidade Nordestina em Feiras de Ciências em Pernambuco", financiado pelo Ministério da Ciência e Tecnologia/CNPq (Edital 51/2010).

Como docentes e pesquisadores em Ensino de Ciências, propusemo-nos o desafio de elaborar um formato diferente das palestras convencionais centradas na figura mais "experiente" do ministrante. Nesta proposta, o roteiro do curso seria em grande parte definido pelas respostas dos participantes de cada escola, de município, de cada realidade. Fundamentamos nossa perspectiva metodológica em dinâmicas de grupo porque

Trabalhos em grupo podem ser divertidos, estimular a criatividade, ajudar as pessoas a relaxar e criar vínculos e relacionamentos os quais dificilmente aconteceriam em trabalhos individuais. (...) devem estimular questionamentos sobre o modo como a informação é intercambiada, e de como as ideias surgem. Neste cenário, a capacidade de um indivíduo interferir dependerá do comportamento dos demais membros (GORSE; SANDERSON, 2007, p. 295).

O objetivo central de nosso estudo foi examinar as concepções sobre planejamento, procedimentos de execução e acompanhamento de projetos de Feiras de Ciências entre professores do ensino fundamental da rede pública. Ampliamos nosso olhar para conhecer sobre suas dificuldades, percepções e posicionamentos a respeito dos seus enfoques sobre as FC, a abrangência e a universalidade dos temas, o domínio 
de conteúdo pelo professor e a forma de acompanhamento dos projetos. A experiência buscou transcender o momento de "atualização" de conteúdos para materializar-se como uma reflexão sobre a prática docente.

\section{Metodologia}

\section{Natureza da pesquisa e definição do público-alvo}

Este estudo caracteriza-se como exploratório e descritivo quanto à sua natureza e abordagem (GRAY, 2012). Optamos por uma pesquisa qualitativa, por sua capacidade de representar as visões e perspectivas dos participantes de um estudo. Assim, os eventos e ideias oriundos da pesquisa qualitativa podem representar os significados dados a fatos da vida real pelas pessoas que os vivenciam, não os valores, pressuposições, ou significados mantidos por pesquisadores (YIN, 2016).

Quanto aos procedimentos adotados, caracteriza-se como um levantamento e também se apropria do arcabouço metodológico de uma observação participante, uma vez que envolve questionamentos diretos ao público alvo e busca acompanhar, com o mínimo de interferência, as percepções e atitudes de professores a partir de uma atividade em grupo. Ecoamos a visão das Ciências Sociais defendida por William Whyte (2005), ao descrever que na observação participante o pesquisador frequentemente desconhece as teias de relações e hierarquias do grupo; ele é um observador que está sendo continuamente observado (grifo nosso). Valladares (2007), comentando sobre as contribuições de Whyte na Etnografia, acrescenta que o pesquisador se equivoca ao pressupor que dispõe de controle da situação ou que será transformado em um dos pares. Por mais que se pense inserido, paira sobre ele a curiosidade ou a desconfiança dos observados:

Por isso mesmo o pesquisador deve mostrar-se diferente do grupo pesquisado. Seu papel de pessoa de fora terá que ser afirmado e reafirmado. Não deve enganar os outros, nem a si próprio. O pesquisador quase sempre desconhece sua própria imagem junto ao grupo pesquisado. Seus passos durante o trabalho de campo são conhecidos e muitas vezes controlados por membros da população local (VALLADARES, 2007, p. 154).

A pesquisa foi desenvolvida com professores de Ciências da rede municipal de Pernambuco, das quatro regiões administrativas do Estado, sendo: Capital, Zona da 
Mata, Agreste e Sertão. As atividades foram desenvolvidas em oito municípios, com diferentes características de renda, população e indicadores educacionais, a fim de incluir regiões tradicionalmente alijadas de iniciativas de extensão universitária, por sua distância dos centros de formação e pesquisa, e também para ampliar a diversidade de percepções e contribuições para o debate (Quadro 1).

A atividade originou-se de um curso de extensão oferecido a secretarias de Educação de 12 municípios de Pernambuco das quais oito manifestaram interesse e autorizaram a participação dos professores, disponibilizando também a infraestrutura necessária. Diferentemente de "capacitações" formais previstas no calendário dos professores, nossa proposta envolveu a adesão espontânea dos participantes, sem qualquer "retribuição" além de um certificado emitido pela Proext/UFPE. O número de participantes em cada município variou de 17 a 41, perfazendo um total de 210 participantes, dos quais $130(61,9 \%)$ eram do sexo feminino e $80(38,1 \%)$ eram do sexo masculino (Quadro 2). Os professores tinham idade variável (de 24 a 56 anos) e tempo de experiência condizente com sua conclusão de curso; todos os docentes eram efetivos e afirmaram lecionar desde a conclusão de sua graduação em Licenciatura (100\%). Dos 210 participantes, 42 (20\%) possuíam alguma pós-graduação na área de Ensino. Quando indagados se já haviam realizado FC, cerca de $65 \%$ afirmaram ter "alguma" experiência com este tipo de intervenção didática.

Quadro 1. Breve caracterização dos municípios selecionados para realização desta pesquisa, de acordo com sua localização, indicadores populacionais e educacionais à época do estudo.

\begin{tabular}{|c|c|c|c|c|c|c|}
\hline & Município & $\begin{array}{l}\text { Localiza- } \\
\text { ção }\end{array}$ & População & $\begin{array}{c}\text { IDEB } \\
\text { Municipal }\end{array}$ & $\begin{array}{c}\mathbf{N}^{0} \text { total de } \\
\text { professo- } \\
\text { res } \\
\text { Rede } \\
\text { municipal* }\end{array}$ & $\begin{array}{c}\mathbf{N}^{0} \text { total de } \\
\text { escolas } \\
\text { Rede } \\
\text { municipal }^{*}\end{array}$ \\
\hline Capital & Recife & $\begin{array}{l}\text { 08o03'14"S; } \\
\text { 34o52'52"O }\end{array}$ & 1.537 .704 & 4,3 & 2.805 & 211 \\
\hline $\begin{array}{l}\text { Zona da } \\
\text { Mata }\end{array}$ & Vicência & $\begin{array}{l}\text { 07o39'25"S; } \\
\text { 35019'37"O }\end{array}$ & 30.880 & 3,2 & 181 & 24 \\
\hline
\end{tabular}




\begin{tabular}{|c|c|c|c|c|c|c|}
\hline \multirow[t]{4}{*}{ Agreste } & Limoeiro & $\begin{array}{l}\text { 07o52'20"S; } \\
\text { 35o26'23"O }\end{array}$ & 55.439 & 4,7 & 207 & 26 \\
\hline & Gravatá & $\begin{array}{l}\text { 08o12'03"S; } \\
\text { 35o33'59"O }\end{array}$ & 77.850 & 4.0 & 345 & 66 \\
\hline & $\begin{array}{l}\text { Bom Con- } \\
\text { selho }\end{array}$ & $\begin{array}{l}\text { 09o09'51"S; } \\
\text { 36o40'60"O }\end{array}$ & 45.506 & 3,9 & 280 & 48 \\
\hline & Belo Jardim & $\begin{array}{l}\text { 08o20'09"S; } \\
36 \circ 25^{\prime} 26 " \mathrm{O}\end{array}$ & 72.720 & 4,3 & 430 & 67 \\
\hline \multirow[t]{2}{*}{ Sertão } & Sertânia & $\begin{array}{l}\text { 08o04'14"S; } \\
\text { 37o15'57"O }\end{array}$ & 33.950 & 4,3 & 219 & 47 \\
\hline & Petrolina & $\begin{array}{l}\text { 09o23'55"S; } \\
40 \circ 30 \text { '03"O }\end{array}$ & 293.962 & 5,1 & 923 & 75 \\
\hline
\end{tabular}

\section{Descrição da atividade}

O curso teve duração total de oito horas, e foi ministrado em um único dia. Os locais em cada cidade variaram desde escolas municipais, sedes de Secretaria de Educação, ou até mesmo a Câmara Municipal de Vereadores. Os encontros presenciais nos municípios de origem dos professores iniciaram-se com a apresentação dos mediadores e dos participantes. Discutimos brevemente o objetivo do encontro de formação junto aos professores, a saber: promover uma discussão sobre a importância das Feiras de Ciências como ferramenta de ensino e pesquisa, incorporando no percurso as experiências dos envolvidos e as construções geradas durante as apresentações. Neste sentido, o curso foi iniciado com uma roda de conversa sobre a prática docente de cada participante, socializando suas experiências prévias com FC. Em seguida, houve apresentações orais dos mediadores com projeção de slides para apresentação de alguns marcos teóricos sobre a inter-relação entre FC e o ensino por investigação. De modo breve, socializarmos algumas experiências do Grupo de Pesquisa em Ensino de Biologia da UFPE para que, quebrado o "gelo" inicial, a dinâmica de grupo pudesse ser iniciada. Nesta dinâmica, a partir das fichas de inscrição dos participantes, foram formados grupos heterogêneos de professores, ou seja, alocando em cada grupo professores que trabalhavam em escolas diferentes no município.

Para apreciar as concepções prévias dos professores, optamos pela aplicação de uma atividade lúdica, referendados pela adoção de dinâmicas de grupo como ponto 
de partida para a discussão de conceitos, percepções, concepções e atitudes. A partir da perspectiva de Heron (1999), que descreve três modelos de mediação do professor facilitador (hierárquico, cooperativo e autônomo), optamos por este último. No modelo autônomo, o facilitador proporciona espaço para a prática auto orientada e os membros do grupo são livres para lidar com ideias, conflitos, resistências e lideranças, estando o facilitador responsável por criar condições para o trabalho produtivo (HERON, 1999).

Dentre uma miríade de formatos e possibilidades para conhecer a percepção dos professores sobre FC, e considerando a limitação de tempo, evitamos aplicar questionários e entrevistas, as quais, apesar de suas vantagens na pesquisa qualitativa, podem se constituir em instrumentos intimidantes e pouco frutíferos, especialmente no caso de perguntas abertas mais complexas que demandassem tempo maior de resposta. Como solução, criamos um instrumento aparentemente simples, mas capaz de estimular o debate entre os docentes, e que permitisse ao observador conhecer percepções e posicionamentos.

Como instrumento para exploração de percepções e atitudes dos professores, criamos um "roteiro de viagem", a partir do qual o destino seria construído a partir de respostas a questionamentos sobre Feiras de Ciências. Este instrumento combinou os eixos metodológicos priorizados em nosso estudo: o rigor da pesquisa científica qualitativa, a ludicidade tão ausente nas ações de formação continuada de professores, e os fundamentos da dinâmica de grupo na qual os integrantes precisam exercer competências de afirmação, negociação, concessão, representação. $\mathrm{Na}$ Viagem Científica o grupo - sempre que possível formado por um número ímpar de participantes - deveria chegar a um consenso sobre afirmações intencionalmente antagônicas e sem posicionamentos intermediários. Isso foi elaborado para gerar uma provocação ao professor sobre seu posicionamento entre extemos tão diversos e alimentar o debate entre os colegas. O grupo deveria sempre assinalar uma das duas opções, e essa opção representaria a maioria - nem todos os integrantes se sentiriam representados pela resposta, e isto enriqueceu o debate posterior. Caso o grupo optasse pela letra "a", a rota tomaria o rumo da esquerda, e caso optasse pela "b", seguiria pelo lado direito do mapa até chegar ao número seguinte, o qual estaria associado a uma nova afirmação, e assim consecutivamente até chegar ao destino final (Quadro 2, Figura 1). 
A partir da seleção consecutiva e interdependente de quatro respostas, o grupo chegaria a um determinado destino. Para reforçar a analogia com uma viagem, os resultados finais eram representados por cidades, tanto de Pernambuco (reforçando a visibilidade do universo docente) como de outros estados e países, conferindo um caráter lúdico à prática. $\mathrm{O}$ formato da atividade mescla elementos das Ciências da Natureza - como a sequência de chaves taxonômicas dicotômicas, bastante comuns na identificação de seres vivos, com a brincadeira, o escapismo, a oportunidade de sair de seu município e "viajar por um dia". Para entrar no clima, fotografias dos destinos eram projetados na tela para reforçar o aspecto de viajantes. Notamos que os professores se mostraram muito mais receptivos com esta dinâmica do que se fossem expostos a uma batelada de perguntas formais sobre sua rotina de trabalho - como se sentiriam diante de estranhos que parecem estar julgando se as atividades que desenvolvem são "certas" ou "erradas"?

Quadro 2. Ficha de questionamentos-base para a Viagem Científica

\begin{tabular}{|c|c|}
\hline \multicolumn{2}{|c|}{ Olá, professor(a)! } \\
\hline $\begin{array}{l}\text { A } \\
\mathbf{K}\end{array}$ & $\begin{array}{l}\text { O mais importante de um projeto de Feira de Ciências deve ser o resultado alcançado } \\
\text { pelos estudantes, com a apresentação de algo inovador e com mérito científico. }\end{array}$ \\
\hline \multirow[t]{3}{*}{1} & OU \\
\hline & $\begin{array}{l}\text { O mais importante de um projeto de Feira de Ciências deve ser o processo de } \\
\text { envolvimento dos estudantes, com o assunto, com o professor e dentro da própria } \\
\text { equipe, mesmo que o resultado final seja fraco. }\end{array}$ \\
\hline & $\begin{array}{l}\text { Um professor deve dar o máximo de independência para que os estudantes escolham } \\
\text { o tema, a metodologia, as fontes de informação e o formato do projeto a ser } \\
\text { apresentado. }\end{array}$ \\
\hline 2 & OU \\
\hline $\begin{array}{l}\mathrm{B} \\
\lambda\end{array}$ & $\begin{array}{l}\text { O professor deve acompanhar de perto todas as etapas de desenvolvimento da Feira } \\
\text { de Ciências, corrigindo e orientando cada etapa, mesmo que isso comprometa um } \\
\text { pouco a liberdade criativa do estudante. }\end{array}$ \\
\hline $\begin{array}{l}\text { A } \\
\boldsymbol{K}\end{array}$ & $\begin{array}{l}\text { Se eu abordar apenas temas locais nos projetos de Feiras de Ciências eu estarei } \\
\text { oferecendo uma visão limitada do papel dos cientistas. }\end{array}$ \\
\hline 3 & OU \\
\hline $\begin{array}{l}\mathrm{B} \\
\pi\end{array}$ & $\begin{array}{l}\text { Eu devo sempre abordar apenas temas próximos à realidade do estudante, pois isso } \\
\text { facilita a sua identificação com problemas e situações reais. }\end{array}$ \\
\hline $\begin{array}{l}\text { A } \\
\boldsymbol{K}\end{array}$ & $\begin{array}{l}\text { Como professor, eu tenho a obrigação de entender muito sobre todos os temas a } \\
\text { serem explorados nas Feiras. }\end{array}$ \\
\hline 4 & OU \\
\hline $\begin{array}{l}\mathrm{B} \\
\pi\end{array}$ & $\begin{array}{l}\text { Como professor eu posso dar orientações gerais sobre o assunto e a metodologia, } \\
\text { mas não tenho obrigação de entender bastante sobre o tema trabalhado. }\end{array}$ \\
\hline
\end{tabular}


A partir de nossa experiência prévia em formação continuada de professores, selecionamos quatro aspectos - dentre tantos importantes - para serem contemplados entre os questionamentos: 1) a forma de avaliação dos resultados das FC; 2) o acompanhamento dos alunos durante os projetos; 3) o escopo dos temas dos projetos - se priorizados temas essencialmente locais ou aqueles de caráter global, e 4) o papel do professor como orientador especialista no tema contemplado.

Ao longo da dinâmica, os professores foram informados de que as atividades não tinham qualquer caráter avaliativo e que não havia respostas certas e nem erradas. Após o tempo necessário para dirimir as dúvidas, foi dado um tempo médio de 50 a 60 minutos para que todos os grupos chegassem a um destino. Durante a prática, os mediadores deste trabalho registraram em notebook comentários decorrentes dos debates dos professores dentro de seus grupos. Após todos os grupos terem atingido um destino, realizou-se uma plenária na qual os professores apresentavam suas respostas e comparavam-nas com as dos colegas. Com base no destino alcançado e suas diferenças e semelhanças - buscou-se identificar a partir de qual ponto do percurso as divergências evoluíram. Desta forma, os professores eram estimulados a elaborar sobre as razões para suas opções de resposta. Um tempo de 60 a 90 minutos foi reservado para este debate, dentro de cada grupo. Ao final, um debate coletivo foi promovido para resgatar opiniões, críticas e considerações inicialmente sobre Feiras de Ciências, mas a conversa ampliou-se espontaneamente para contemplar a atmosfera de trabalho em cada município, em cada escola, e na educação pública como um todo.

Para obtenção dos dados utilizamos diversos indicadores, partindo principalmente do "destino" final alcançado por cada grupo. A partir daí, "retrocedemos" a viagem para compreender em que momentos os percursos convergiram ou divergiram a partir dos posicionamentos de cada questionamento. Desta forma, um dos mediadores gerenciava as apresentações, opiniões e debates dos professores em formação. Paralelamente, o outro mediador registrava, com a autorização prévia dos participantes, as falas colocadas para as defesas de suas escolhas dentre as alternativas, respeitando-se a regra inicial da "fala coletiva" (opção negociada do grupo) para em seguida ouvir as opiniões individuais (concordantes ou discordantes do resultado de cada grupo). Ao longo das inúmeras falas registradas nos oito municípios, selecionamos algumas para serem transcritas neste texto como forma de validação das categorias e análises. 
Figura 1: Representação do roteiro para o mapa da Viagem Científica.

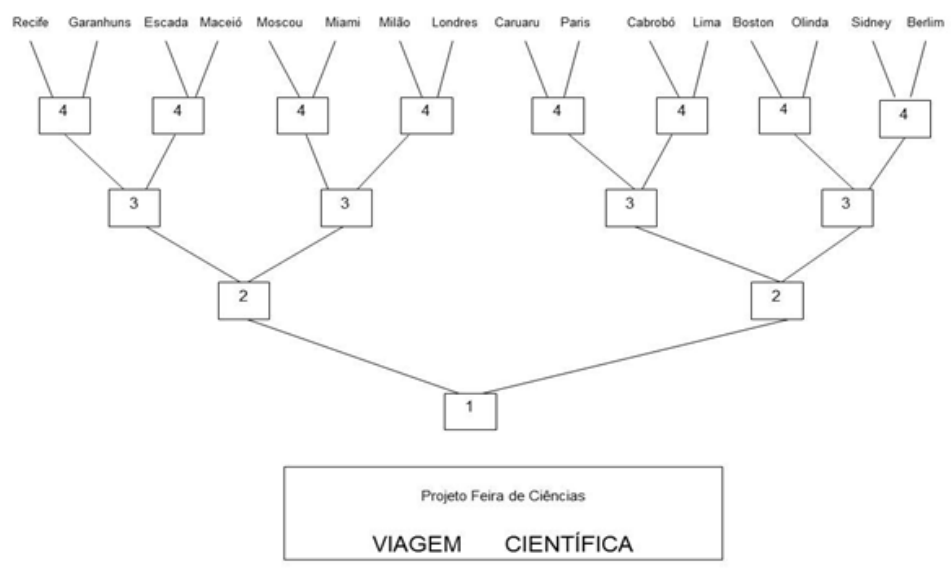

Embora o estudo seja qualitativo, os resultados foram organizados em planilhas para quantificação, em percentagem, das respostas aos questionamentos. Ao final da atividade, os participantes autorizaram a divulgação dos resultados de forma a respeitar o anonimato dos envolvidos. Tão importante quanto a definição do destino em si, as concepções dos professores formaram a base da construção de um rico painel de percepções e posicionamentos sobre o tema FC em escolas públicas de Pernambuco.

\section{Resultados e Discussão}

\section{Considerações sobre a execução da atividade lúdica}

Inicialmente, observamos que os participantes se mostraram hesitantes em expressar suas concepções sobre o planejamento e o acompanhamento de projetos de Feiras de Ciências. Isto aponta para questionamentos interessantes: que tipo de formação continuada estes docentes vêm recebendo? “Capacitações” impessoais nas quais um palestrante veicula uma série de informações "corretas" sobre um tema ou metodologia sem fomentar a valorização dos saberes experienciais dos participantes? Será que municípios pequenos de zonas distantes das capitais recebem formação continuada em consonância com as práticas do ensino por investigação, 
amplamente defendido e debatido em reuniões, congressos e encontros do campo educacional e de ensino de Ciências e Biologia? No curso de extensão, observamos que secretários municipais manifestaram surpresa ao serem informados de que o município havia sido convidado para uma iniciativa totalmente gratuita e sem exigência de contrapartidas, o que nos fez refletir sobre os desafios de professores das universidades públicas em atingir um público-alvo distante dos grandes centros de excelência em ensino e pesquisa.

Professores de todos os grupos em todos os municípios questionaram os mediadores da atividade sobre a possibilidade de atingir um "meio termo" entre as respostas, pois alegavam não concordar totalmente com uma única opção. Da mesma forma, em muitos grupos houve dificuldades em se chegar a um consenso, pois alguns professores resistiam em ser representados pela opinião da maioria quando a resposta escolhida pelo grupo discordava da sua - e expuseram essa divergência nas plenárias. Ao longo da prática, manifestavam receio em escolher a opção "incorreta", mesmo após assegurarmos que ambas as categorias representavam posicionamentos igualmente válidos. Consideramos esse "desconforto" salutar, e devolvemos o questionamento aos próprios professores. Como vocês se sentem defendendo uma ideia com a qual não concordam entusiasticamente? Que argumentos você precisa construir para defender uma ideia? Como você lida com a ideia de que uma afirmação sobre Ensino não precisa necessariamente ser categorizada como apenas "certa" ou "errada" (grifo nosso). O debate foi enriquecido com as colocações dos professores, os quais, aos poucos, começaram a se sentir mais à vontade para confrontar, discordar e explicar seus pontos de vista.

A dinâmica de grupo da Viagem Científica auxiliou a "quebrar o gelo" da apatia inicial observada entre os participantes. Permitiu uma troca de ideias entre professores com pouco ou nenhum conhecimento mútuo ou sobre a realidade profissional do colega, já que alguns trabalhavam em escolas da zona urbana e outros na zona rural do mesmo município. Também cumpriu seu objetivo de promover o debate - que se iniciou de forma tímida e culminou na participação calorosa de todos os envolvidos, e por fim contribuiu, mesmo que de forma pontual, como uma semente para a possível (re)construção de conceitos, evidenciada a partir das falas dos docentes, quando afirmavam que pensavam de uma forma, mas a partir do debate com os colegas, passaram a "pensar diferente". Nós, mediadores, evitamos expressar com qual afirmação nós nos identificávamos mais, o que chegou a surpreender 
alguns participantes que esperavam que ao final houvesse um "gabarito" com as respostas absolutas. O exemplo do percurso seguido por cada equipe é ilustrado na Figura 2, demonstrando pontos de "divergência" a partir dos quais os destinos eram alcançados.

Curiosamente, os professores demonstraram surpresa ao detectar a enorme variedade de "destinos finais" (Quadro 2), apesar do fato de todos pertencerem à rede de ensino público do município e do mesmo nível do ensino - ou seja, compartilharem realidade escolar semelhante. Esta heterogeneidade de abordagens não surpreende, uma vez que decorre de uma miríade de histórias pessoais e profissionais, de experiências docentes distintas que se materializam no universo escolar, como destacado por Opfer e Pedder (2011):

A aprendizagem do professor tende a se constituir simultaneamente na atividade de entidades autônomas (professores), coletivas (grupos de professores por área ou nível) e subsistemas dentro de unidades maiores (escolas dentro de sistemas escolares e inseridas em contextos educacionais sociopolíticos). Como resultado, para entender a aprendizagem profissional do professor, deve-se entender como a variedade de conhecimento local, problemas, rotinas e aspirações molda e é moldada por concepções e práticas individuais” (OPFER; PEDDER, 2011, p. 378).

Figura 2. Exemplo de roteiro percorrido por professores para atingir determinado destino, a partir de suas respostas aos questionamentos

\begin{tabular}{|l|l|l|}
\hline \multicolumn{2}{|l|}{$\begin{array}{l}\text { Considerando que o grupo de professores optou por concordar com as afirmações abaixo, a rota seguida pelo } \\
\text { roteiro culminaria no destino final: Londres }\end{array}$} \\
\hline 1 & A & $\begin{array}{l}\text { O mais importante de um projeto de Feira de Ciências deve ser o resultado alcançado pelos } \\
\text { estudantes, com a apresentaç̃o de algo inovador e com mérito cientifico. }\end{array}$ \\
\hline $\mathbf{2}$ & B & $\begin{array}{l}\text { O professor deve acompanhar de perto todas as etapas de desenvolvimento da Feira de Ciências, } \\
\text { corrigindo e orientando cada etapa, mesmo que isso comprometa um pouco a liberdade criativa do } \\
\text { estudante. }\end{array}$ \\
\hline 3 & B & $\begin{array}{l}\text { Eu devo sempre abordar apenas temas próximos à realidade do estudante, pois isso facilita a sua } \\
\text { identificacão com problemas e situacões reais. }\end{array}$ \\
\hline 4 & B & $\begin{array}{l}\text { Como professor eu posso dar orientaçoses gerais sobre o assunto e a metodologia, mas não tenho } \\
\text { obriqacão de entender bastante sobre o tema trabalhade. }\end{array}$ \\
\hline
\end{tabular}

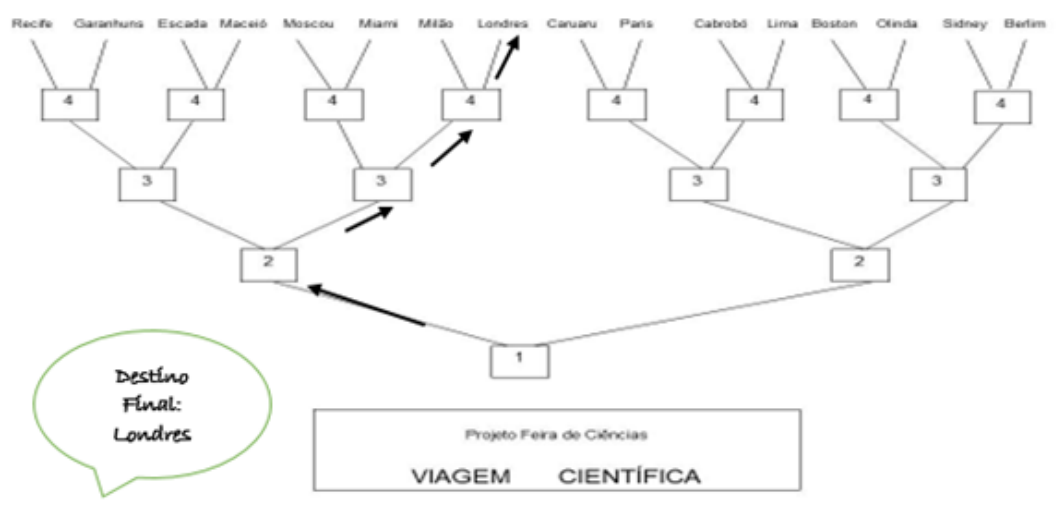


Ao longo da prática, detectamos divergências de percepções, estratégias de mediação de situações antagônicas, e posicionamentos com diferentes graus de comprometimento sobre os temas. Curiosamente, o destino final alcançado com maior frequência foi Berlim, o qual por estar na extrema direita do roteiro, representava um posicionamento mais favorável ao entendimento de que a avaliação das feiras deve priorizar o processo em detrimento ao produto. Adicionalmente, para se chegar a Berlim, os professores escolheram afirmações que representavam um maior monitoramento dos estudantes e a seleção de temas mais próximos da realidade escolar, contrapondo-se a uma forma mais "livre" de desenvolver FC ou à opção de escolher temas mais universais (Quadro 2, Apêndice 1).

\section{Avaliar o processo ou o produto? O professor tem a palavra!}

A quantificação das respostas para cada questionamento encontra-se no Quadro 3. Quanto ao dualismo entre processo vs. produto para avaliação das FC, aproximadamente $33 \%$ dos professores consideram o produto como o mais significante para representar o sucesso e a importância deste tipo de projeto didático. Esta tendência é exemplificada na fala de um professor de Gravatá: "Se o resultado do projeto foi bom, então é porque o processo funcionou corretamente", ao considerar que o produto em si pressupõe entendimento suficiente para significar o que aconteceu no projeto e o que simbolizaram as Feiras.

Ainda que reconheçam a importância do processo, os professores justificam que sua avaliação impõe enorme dificuldade para acompanhar o desenrolar das atividades, em um contexto permeado pelo limitado tempo, pelo interesse aparentemente fraco dos estudantes em cumprir prazos e pela precária infraestrutura que as escolas disponibilizam para sua execução (laboratórios e espaços extraclasse, por exemplo). Em muitos casos, e até com o consentimento dos professores, os estudantes já chegam com o produto "pronto" para as Feiras, o que inviabiliza ao professor compreender e avaliar como o processo realmente aconteceu.

Contrapondo-se à ênfase no produto, $67 \%$ dos professores atribuem ao processo o critério mais importante para avaliar as feiras por defenderem que esses momentos de aprendizagem beneficiam, durante a sua vivência, a consolidação de competências e conhecimentos e a superação de dúvidas dos estudantes. Desta forma, compreendem que validar as feiras somente por meio do produto compromete 
o diagnóstico dos acontecimentos, acordos e superações de obstáculos, de entendimentos científicos equivocados e corrigidos na (con)vivência de professores e estudantes durante a construção do conhecimento (WERNECK, 2006; BACHELARD, 2007). Ao considerarmos o campo de conhecimentos das Ciências da Natureza, com olhar para a teoria de Bachelard (2007), é de se reconhecer a existência de diversas definições e conceituações, do micro ao cosmos, em que se exige do estudante um elevado grau de abstração para a materialização desses saberes. Assim, as FC concretizam oportunidades para identificar quais propostas argumentativas foram estabelecidas, que ideias foram superadas e/ ou aplicadas e que tipos de dificuldades os estudantes tiveram que superar para alcançar os resultados então construídos e expostos como resultado de seus projetos.

Quadro 2. Perfil geral dos destinos finais selecionados na dinâmica de grupo "Viagem Científica", realizada com professores de Ciências da rede municipal de Pernambuco. Em sombreado indicamos as opções de respostas mais frequentes.

\begin{tabular}{|c|c|c|c|c|c|c|c|c|}
\hline Indicador & RE & GR & VI & LI & BC & B J & PE & SE \\
\hline $\begin{array}{l}\mathrm{N}^{\circ} \text { de profes- } \\
\text { sores }\end{array}$ & 17 & 34 & 26 & 20 & 18 & 41 & 21 & 33 \\
\hline $\mathrm{N}^{0}$ de grupos & 05 & 08 & 08 & 05 & 05 & 08 & 06 & 11 \\
\hline $\begin{array}{l}N^{0} \text { de desti- } \\
\text { nos }\end{array}$ & 04 & 04 & 06 & 04 & 03 & 05 & 04 & 07 \\
\hline $\begin{array}{c}\text { D e s t i n o } \\
\text { escolhido }\end{array}$ & \multicolumn{8}{|c|}{ Frequência relativa } \\
\hline Recife & - & - & - & - & - & - & $16,7 \%$ & - \\
\hline Garanhuns & - & - & - & - & - & - & & $9,1 \%$ \\
\hline Escada & - & - & - & - & - & - & - & - \\
\hline Maceió & - & - & - & - & - & - & - & - \\
\hline Moscou & $20,0 \%$ & $12,5 \%$ & $12,5 \%$ & - & $20,0 \%$ & $12,5 \%$ & - & $9,1 \%$ \\
\hline Miami & $20,0 \%$ & - & & - & - & - & - & - \\
\hline Milão & - & - & $12,5 \%$ & $20,0 \%$ & - & $12,5 \%$ & - & $27,2 \%$ \\
\hline Londres & - & - & $12,5 \%$ & $20,0 \%$ & - & - & - & $18,2 \%$ \\
\hline \multicolumn{9}{|c|}{ Opções identificadas com a valorização do processo } \\
\hline Caruaru & - & - & - & - & - & - & - & - \\
\hline Paris & - & - & - & - & - & - & - & - \\
\hline Cabrobó & - & - & - & - & - & $12,5 \%$ & - & - \\
\hline Lima & - & $12,5 \%$ & - & - & - & - & - & - \\
\hline Boston & - & - & - & - & - & - & $16,7 \%$ & - \\
\hline
\end{tabular}




\begin{tabular}{|l|l|l|l|l|l|l|l|l|}
\hline Olinda & $20,0 \%$ & $62,5 \%$ & $37,5 \%$ & $20,0 \%$ & - & - & $33,3 \%$ & $9,1 \%$ \\
\hline Sidney & - & - & $12,5 \%$ & $40,0 \%$ & $20,0 \%$ & $25,0 \%$ & - & $18,2 \%$ \\
\hline Berlim & $40,0 \%$ & $12,5 \%$ & $12,5 \%$ & - & $60,0 \%$ & $37,5 \%$ & $33,3 \%$ & $9,1 \%$ \\
\hline
\end{tabular}

Legenda: Recife - RE; Gravatá - GR; Vicência - VI; Limoeiro - LI; Bom Conselho - BC; Belo Jardim - BJ; Petrolina - PE; Sertânia - SE.

Os professores que se identificaram com esta linha de trabalho compreendem que o mais importante é o processo da descoberta, mesmo que o resultado final seja abaixo do esperado, como alegado por um professor de Limoeiro: "Prefiro que os estudantes façam algo fraco, mas contanto que eles façam sozinhos”. Com exceção dos professores do município de Sertânia, a maioria defende que um bom processo oportuniza maior aprendizagem e construção do conhecimento por parte dos estudantes, e que mesmo a perspectiva de um trabalho "imperfeito" ao final do projeto não desqualifica o sucesso da iniciativa e a execução dos objetivos programados. Se tomarmos o percurso para a construção das feiras como uma estratégia de aprendizagem para os estudantes, é de se esperar que as negociações e descobertas pelos estudantes participantes do projeto contribuam significativamente para a apropriação de conhecimentos científicos e para o desenvolvimento de técnicas e habilidades também essenciais à formação do sujeito social.

Quadro 3. Quantificação das respostas de professores de escolas públicas municipais de Pernambuco a respeito de suas concepções sobre Feiras de Ciências. Em sombreado indicamos as opções de respostas mais frequentes.

\begin{tabular}{|l|l|l|l|l|l|l|l|l|}
\hline \multicolumn{1}{|c|}{ Eixo central da ideia } & \multicolumn{7}{|c|}{ Município } \\
\hline & RE & GR & VI & LI & BC & BJ & PE & SE \\
\hline $\begin{array}{l}\text { A Feira de Ciência prioriza } \\
\text { o produto }\end{array}$ & $40,0 \%$ & $12,5 \%$ & 37,5 & 40,0 & 20,0 & 25,0 & 16,7 & $63,6 \%$ \\
\hline $\begin{array}{l}\text { A Feira de Ciência prioriza } \\
\text { o processo }\end{array}$ & $60,0 \%$ & $87,5 \%$ & $62,5 \%$ & $60,0 \%$ & $80,0 \%$ & 75,0 & $83,3 \%$ & 36,4 \\
\hline & & & & & & & & \\
\hline $\begin{array}{l}\text { O estudante deve ter total } \\
\text { autonomia }\end{array}$ & - & $12,5 \%$ & - & - & - & $12,5 \%$ & $16,7 \%$ & $9,0 \%$ \\
\hline $\begin{array}{l}\text { O estudante deve ser } \\
\text { acompanhado de perto sob } \\
\text { orientação do docente }\end{array}$ & $100 \%$ & $87,5 \%$ & $100 \%$ & $100 \%$ & $100 \%$ & $87,5 \%$ & $83,3 \%$ & $91,0 \%$ \\
\hline & & & & & & & & \\
\hline $\begin{array}{l}\text { Aplicação de temas globais } \\
\text { / universais }\end{array}$ & $60,0 \%$ & $75,0 \%$ & $50,0 \%$ & $20,0 \%$ & $20,0 \%$ & $12,5 \%$ & $66,7 \%$ & $27,3 \%$ \\
\hline
\end{tabular}




\begin{tabular}{|l|l|l|l|l|l|l|l|l|}
\hline $\begin{array}{l}\text { Aplicação de temas locais / } \\
\text { contextualizado }\end{array}$ & $40,0 \%$ & $25,0 \%$ & $50,0 \%$ & $80,0 \%$ & $80,0 \%$ & $87,5 \%$ & $33,3 \%$ & $72,7 \%$ \\
\hline & & & & & & & & \\
\hline $\begin{array}{l}\text { O professor como especia- } \\
\text { lista nos assuntos da Feira }\end{array}$ & $20,0 \%$ & $12,5 \%$ & $37,5 \%$ & $60,0 \%$ & $40,0 \%$ & $62,5 \%$ & $33,3 \%$ & $54,5 \%$ \\
\hline $\begin{array}{l}\text { O professor como aprendiz } \\
\text { juntamente com o estu- } \\
\text { dante }\end{array}$ & $80,0 \%$ & $87,5 \%$ & $62,5 \%$ & $40,0 \%$ & $60,0 \%$ & $37,5 \%$ & $66,7 \%$ & $45,5 \%$ \\
\hline
\end{tabular}

Legenda: Recife - RE; Gravatá - GR; Vicência - VI; Limoeiro - LI; Bom Conselho - BC; Belo Jardim - BJ; Petrolina - PE; Sertânia - SE.

\section{A difícil decisão entre a autonomia e o controle}

De acordo com Jiménez Raya, Lamb e Vieira (2007), a autonomia pode ser compreendida como a "competência para se desenvolver como participante autodeterminado, socialmente responsável e criticamente consciente em (e para além de) ambientes educativos, por referência a uma visão da educação como espaço de emancipação (inter)pessoal e transformação social" (p. 205). Quanto à promoção da autonomia no desenvolvimento do projeto, a maioria dos professores afirma optar por reduzir a independência do estudante para acompanhá-lo de perto, alegando que assume esta postura para evitar que a experiência culmine com um trabalho de qualidade inferior (Quadro 02). Este posicionamento observado nos oito municípios é ilustrado pela fala de um professor de Belo Jardim: "Se a gente não acompanhar de perto, os estudantes deixam para a última hora", evidenciando que o acordo didático entre estudante e professor parece não ser cumprido em termos de confiança na responsabilidade dos estudantes.

Ao se discutir a autonomia do estudante na construção das FC, nem sempre é possível delimitar fronteiras entre o que seria o "acompanhar de perto" e um "controle" intenso por parte do orientador. Ao mesmo tempo que a interferência do professor contribui para minimizar imprevistos nos procedimentos, o controle excessivo, com adoção de regras inflexíveis e imposição de procedimentos sem a devida participação do estudante pode ser contraproducente. O dilema explicitado pelos professores da rede pública de Pernambuco é uma situação compartilhada por docentes de outros contextos, inclusive em outros países, uma vez que 
o apoio à autonomia é um comportamento interpessoal no qual [o professor] nutre as intenções voluntárias, de motivação interna, para agir, como quando um professor estimula necessidades psicológicas (competência e pertinência), interesses, preferências e valores. (...) O suporte à autonomia envolve a busca de mecanismos para nutrir, suportar, e aumentar a validação interna dos estudantes sobre sua atividade em sala de aula (REEVE; JANG, 2006, p.210).

Estimular a liberdade para o estudante desenvolver um projeto não significa cercear sua criatividade ou reduzir a possibilidade do risco e do erro - aspectos a serem valorizados no amadurecimento do pensamento crítico e reflexivo. A noção de que erros são uma importante parte da atividade humana foi defendida por pensadores como John Stuart Mill, Bertrand Russell, John Dewey e Karl Popper (SWARTZ, 1976) e sua ocorrência como um fato natural no planejamento e desenvolvimento de atividades didáticas ainda é pouco investigado. Neste sentido, o erro não deve ser encarado como um insucesso, mas sim como

a manifestação de uma conduta não aprendida, que emerge a partir de um padrão de conduta cognitivo, e que serve de ponto de partida para o avanço (...) em direção à aprendizagem do aluno, possibilitando a sua correção de forma hábil e inteligente. Isso significa uma forma consciente e elaborada, na conduta docente, em interpretar o erro na aprendizagem como uma possibilidade de crescimento e valorização do aluno bem como um passo à frente na relação professor-aluno (NAGARO; GRINELLA, 2004, p. 9-10).

A obtenção de resultados distintos do esperado pode causar desconforto no mais experiente dos professores, pois paradigmaticamente ainda não conseguimos nos libertar inteiramente de ritos metodológicos que definem o como proceder, o passo a passo a ser seguido, sem a liberdade de contrariar os pressupostos do método científico convencionalmente estabelecido. Neste sentido, é pertinente lembrar Bachelard (2007) quando ele defende que "diante de uma experiência bem específica que possa ser consignada como tal, como verdadeiramente una e completa, sempre será possível ao espírito científico variar-lhes as condições, em suma, sair da contemplação do mesmo para buscar o outro, para dialetizar a experiência” (p. 21), e então se envolver em situações distintas das já esperadas como resultado da pesquisa.

Para Reeve e Jang (2006), o professor que promove a autonomia permite que os estudantes manipulem materiais e trabalhem ideias, e frequentemente os consulte sobre suas necessidades, estando aberto a sugestões sobre procedimentos de pesquisa e engajados a motivar estudantes pouco interessados. $\mathrm{O}$ professor que medeia a pesquisa junto a seus estudantes necessita compreender que processos e produtos referentes às feiras diferenciam-se de outros percursos de aprendizagem 
já estabelecidos nos ritos da sala de aula. Os momentos das FC simbolizam estratégias de ensino e aprendizagem particulares, distintos de outros em que o professor controla o tempo e "prescreve" quais saberes científicos necessitam ser assimilados pelos estudantes.

O processo de construção da pesquisa oportuniza ao estudante questionar conhecimentos já consolidados e avaliar a coerência desses quando associados aos saberes científicos explorados para as feiras. Adicionalmente, ao estudante é permitido aprofundar estratégias e negociações entre o professor e os membros do grupo, conferindo um caráter emancipatório à atividade. Desta forma, o que se configurava como uma "comprovação" do conhecimento científico cede espaço para a natureza aberta, múltipla, investigativa, divergente do pensar científico

que se concretiza em aspectos fundamentais e erradamente relegados para concepções empírico-indutivas, como são a colocação de hipóteses e de modelos ou a própria concepção de experiências. (...) É necessário chamar aqui a atenção para as interpretações simplistas dos resultados das experiências e para um possível "reducionismo experimentalista": não basta um tratamento experimental para refutar ou comprovar uma hipótese; trata-se sobretudo da existência, ou não, de coerência global com o corpo de conhecimentos vigente (GIL PERÉZ et al., 2001, p. 136).

O conflito registrado entre professores de Pernambuco - característico de muitas escolas públicas brasileiras - encontra eco em realidades distintas de outros países. Por exemplo, um estudo de caso realizado entre professores de escolas públicas da Turquia, observou que $87 \%$ dos professores entrevistados afirmam que a autonomia do estudante na escolha do tema da pesquisa foi uma das etapas mais difíceis na orientação de projetos de Feira de Ciências (TORTOP, 2013). Isto reforça o quanto é complexo para o professor desvencilhar-se desse poder de definir o que e como o estudante deve desenvolver seus estudos e estratégias para as Feiras de Ciências.

\section{Seleção de temas e domínio do conteúdo pelo professor}

A escolha de temas universais para os projetos foi a opção selecionada pela maioria dos grupos, com exceção dos professores dos municípios de Gravatá, Petrolina e Recife (Quadro 3). Neste ponto, os professores pareciam concordar que é imperativo preparar o estudante para "sair dos limites de seu município e ganhar o mundo", como explicitado na fala do professor de Sertânia: “Os efeitos de problemas 
ambientais de outros países também se refletem aqui no município". Ao discutir temas como avanços científicos e tecnológicos, poluição, preservação ambiental e doenças emergentes, entre outros, os professores estimulam a discussão sob um olhar local e contextualizado para a realidade do estudante, aproximando-os da ciência por instiga-los a perceber o quanto seu conhecimento científico construído nas situações de aprendizagem está presente no seu dia a dia, em sua realidade, em seu cotidiano (FINGER; BEDIN, 2019). Da mesma forma, é também possível realizar discussões em âmbito global, conectando-se a outras culturas, nações, contextos e momentos históricos, mas que espelham problemas - reais ou iminentes - a serem vivenciados pela comunidade na qual o estudante se insere.

Entretanto, as respostas dos professores sugerem uma compreensão de que 0 estudo de problemas locais, próximos aos estudantes, parece estimular mais fortemente o seu envolvimento na pesquisa, pois perceberão nos resultados de seu projeto as implicações práticas e propostas de mudanças para a realidade de sua comunidade. Ao entenderem problemas locais, os estudantes consolidarão competências para compreender também problemas semelhantes que acontecem no mundo, pois atualmente o fluxo de informações viabilizado pelos recursos da internet à disposição dos estudantes permite - e estimula - a conexão instantânea com outras realidades.

Nesse contexto, as FC auxiliam o estudante a compreender sua realidade por meio de sua própria experiência de vida. A construção dos projetos a partir dos conhecimentos previamente consolidados extrapola limites por permitir novas compreensões - comparando-as com a realidade de outros povos, outras culturas, outros momentos. No compromisso de ultrapassar fronteiras sem deixar de discutir problemas locais, as FC ampliam possibilidades de construção de conhecimento de forma tão - ou mais - contextualizada que outros recursos e estratégias. Sua elaboração deve oportunizar ao estudante ultrapassar os limites da sala de aula, ampliando conhecimentos que vão além das verdades transcritas nos livros didáticos e replicadas nas falas do professor. Falar do mundo e compreender seus problemas passa a ser o desafio dos professores que, sem a obrigação de dominar todos os conhecimentos, veem-se no compromisso de aprender junto com os estudantes, o que justifica o caráter do professor pesquisador em um contexto do ensino investigativo (ZÔMPERO; LABURÚ, 2011; SASSERON, 2015; FAGUNDES, 2016; NASCIMENTO; GOMES, 2018). 
Por fim, a experiência permitiu gerar dados interessantes sobre como o professor analisa o seu próprio papel na construção das Feiras de Ciências. Para cerca de $40 \%$ dos consultados, o professor precisa dominar os assuntos a serem discutidos pelos estudantes nas feiras, a exemplo da fala de um professor de Belo Jardim: "se a gente demonstrar que não domina completamente o assunto, os estudantes vão perder o respeito", argumento bastante frequente. Para a maioria, o professor deve agir como orientador dos estudantes nas Feiras de Ciências, sem necessariamente ser um especialista nos assuntos abordados no projeto, demonstrando interesse e disponibilidade de aprender sobre o tema juntamente com o estudante, como explicitado por um professor de Gravatá: "A gente não tem obrigação de saber tudo e deve deixar claro para o estudante que também estamos aprendendo", colocando a aprendizagem no projeto como algo compartilhado entre os sujeitos envolvidos no processo.

Embora o conhecimento do conteúdo específico seja imprescindível, no entanto, este é apenas um dos domínios referentes à atuação do professor em sala de aula, $\mathrm{e}$ não é suficiente sem a incorporação do conhecimento dos estudantes, conhecimento pedagógico geral e conhecimento do contexto (ROLLNICK et al., 2008). Sob esta perspectiva, entendemos o quanto o professor pode "flexibilizar" a escolha do tema das FC, exercendo outros domínios do conhecimento pedagógico para acompanhar o processo, orientar os estudantes e incorporar no projeto os procedimentos associados ao ensino por investigação.

Como ressaltado por Richardson (2003) e afirmado em teorias sobre a formação docente (TARDIF, 2000), os pressupostos e concepções prévias que os professores trazem para a sala de aula são moldados pelo tipo de ensino que eles experimentaram quando estudantes. Ou seja, para muitos professores, a concepção sobre a natureza das FC corrobora experiências advindas de suas escolarizações e orientações durante (mas não exclusivamente) seus cursos de graduação. A realidade dos municípios de Pernambuco ainda concentra os grupos de pesquisa sobre Ensino de Ciências próximos à capital, o que limita oportunidades de envolvimento de estudantes de Licenciatura e Pedagogia de municípios localizados distantes geograficamente.

Durante a plenária final, a maioria dos professores afirmou que as poucas oportunidades que tiveram para realizar FC, enquanto estudantes, consistiram de revisões bibliográficas para apresentação de conteúdos fixos, na maioria das vezes desconectados da realidade local. Isto é evidenciado pelo relato de um professor 
de Petrolina: "No meu tempo, a gente estudava sobre um tema e pronto. Fazia um pôster e apresentava para os examinadores... não tinha necessidade de fazer um experimento". Tais relatos justificam a importância de se rediscutir o real sentido das feiras para a educação científica de nossos estudantes, abandonando a noção de simples exposição de conhecimentos já consolidados em livros e artigos.

No constante exercício de se qualificar profissionalmente para contextualizar e problematizar as intervenções investigativas nos diversos espaços de aprendizagem de seus estudantes, merece destaque a reflexão de Tardif (2000):

(...) a formação para o magistério tem um impacto pequeno sobre o que pensam, creem e sentem os alunos [Licenciandos] antes de começar. Na verdade, eles terminam sua formação sem terem sido abalados em suas crenças, e são essas crenças que vão se reatualizar no momento de aprenderem a profissão na prática, crenças essas que serão habitualmente reforçadas pela socialização na função de professor e pelo grupo de trabalho nas escolas, a começar pelos pares, os professores experientes (p. 20).

\section{Considerações Finais}

Evidenciamos aqui como uma atividade formativa de natureza lúdica pode assumir uma dupla função: por um lado, a dinâmica de grupo é uma ferramenta útil para estimular a discussão sobre temas complexos, pois se apropriam da espontaneidade quando comparada a um questionamento direto, escrito ou oral. De modo complementar, a experiência formativa permite subsidiar uma pesquisa destinada a mapear concepções dos professores, verificar suas dificuldades, e encontrar pontos de conflitos e convergências entre colegas docentes - em um mesmo município e em municípios separados geograficamente (como recife e Petrolina) ou em termos de dimensão da rede de ensino municipal (por exemplo, Recife e Limoeiro). Ao mesmo tempo em que estimulam o debate e permitem até mesmo detectar conflitos e dificuldades de compartilhamento de ideias, as dinâmicas de grupo reduzem o caráter de "avaliação" das respostas frequentemente interpretado pelos sujeitos-alvo. Por sua natureza lúdica, a dinâmica da viagem científica contribui para tecer uma rica paisagem de percepções sobre feiras de ciências, e oferecem potencial para planejamento do poder público na formação de professores.

Estudos conduzidos em cinco municípios pernambucanos demonstram que apenas cerca de $20 \%$ dos professores de Ciências da rede municipal costumam promover 
Feiras de Ciências, sendo as causas mais comuns para esta baixa frequência a falta de tempo (37\% das respostas), a falta de estrutura, espaço físico e recursos financeiros $(56 \%)$ e a falta de apoio da escola (22\%) (VASCONCELOS; LIMA, 2012). Por exemplo, algumas das falas mais comuns na plenária ao fim da atividade, incluíam colocações como: "Não temos como garantir um projeto de qualidade se não temos recursos financeiros para os projetos" (professor de Belo Jardim); "Não dá para fazer uma pesquisa científica sem laboratórios e equipamentos" (professor de Gravatá); "A escola não dá suporte para a realização das feiras"; "Faço feiras de Ciências nas outras escolas na qual trabalho [particular], mas não na escola municipal em que ensino" (professor de Belo Jardim).

Ao divulgarmos mostras competitivas de trabalhos, como a "Ciência Jovem", promovida pelo Espaço Ciência de Pernambuco, a maioria dos professores alega não dispor de recursos financeiros e tecnológicos, como se a ausência de uma sofisticação técnica de instrumentação e equipamentos impedisse a consecução de projetos inovadores. Percebe-se também que nenhum dos municípios organiza algum evento para divulgação dos trabalhos dos estudantes. O envolvimento da comunidade externa também se mostra fraco nos oito municípios, a partir das respostas dos participantes.

Diante do receio e da desconfiança expressos pelos professores quanto à falibilidade dos trabalhos surge o desafio de recuperar a credibilidade das FC e o encantamento das pessoas envolvidas, na esperança de que, ao final, o resultado oportunize aprendizagem junto às pessoas envolvidas por se discutir conhecimentos inéditos para os estudantes e para a comunidade. Ou seja, retomar o desejo por estudos que repliquem procedimentos típicos dos cientistas, reinventando modelos de práticas para compreender a construção de conhecimentos científicos já consagrados, sem, no entanto, desconsiderar as possibilidades de construir novos conhecimentos e/ ou entendimentos dos fenômenos com intervenções investigativas que mudem de alguma forma a realidade do estudante expositor e dos visitantes.

A dinâmica com que o conhecimento científico e sua aplicação na sociedade se materializam em nossas salas de aula nos instiga a discutir e aperfeiçoar estratégias e recursos didáticos para melhorar o diálogo entre os sujeitos envolvidos. Com a aplicação da dinâmica "Viagem Científica", houve um exercício constante de convencimento entre os grupos quando as opiniões entre os membros divergiam - um aprendizado de tolerância. Tal exercício valoriza concepções e experiências dos diversos sujeitos nos diferentes modelos mentais construídos sobre FC, a exemplo dos 
comentários citados comumente: "eu escolhi este, mas a maioria do grupo escolheu este outro" - referindo-se às opções da maioria. Assim, compreendemos que estes momentos representam oportunidades para que os professores se conheçam melhor, relatem experiências exitosas e também frustrantes, e trabalhem a argumentação e o poder de convencimento. Esta intervenção se consagra como formação continuada por viabilizar ao professor participante trocas de experiências para refletir sobre o processo e o produto das FC, e repensar sua prática docente no ensino por investigação.

Estratégias de formação continuada são vitais na construção desta práxis. Segundo Philips (2008), o desenvolvimento professional é crítico para a melhoria e manutenção da qualidade da atuação do professor, e seus desdobramentos fluem para a sala de aula. Ainda segundo a autora, os fatores que influenciam o sucesso da formação continuada incluem o potencial para implementação de mudanças, as especificidades do conteúdo e dos métodos, o efeito variável na compreensão dos princípios envolvidos na aprendizagem (já que lidamos com um público acostumado a estar "do outro lado"), e a eficiência das estratégias de mediação e do material utilizado (PHILLIPS, 2008). Gonçalves e Ribeiro (2020) destacam a primordialidade da formação continuada, colocando o professor no centro do processo, para que necessidades formativas possam ser ressignificadas, acarretando assim em uma metamorfose metodológica, no incessante processo de reflexão que é inerente à profissão de professor.

Concordamos com Beck, Czerniak e Lumpe (2000), quando argumentam que os professores são o elemento crítico de uma reforma educacional, pois são fatores decisivos na adoção de uma epistemologia construtivista em sala de aula porque seus pressupostos são os precursores da ação transformadora. Concluímos com uma visão positiva do rico painel de concepções extraídos destes encontros, uma visão plural de ensino e de mundo. Sob a perspectiva da Etnografia, lembramos a fala de Angrosino (2009, p. 29): "A vida humana é fundamentalmente dialógica e polivocal, ou seja, nenhuma comunidade pode ser descrita como uma entidade homogênea em equilíbrio". Neste trabalho, defendemos que a descoberta, valorização e, em alguns casos, a mudança de concepções prévias sobre Feiras de Ciências ampliam a adoção desta ferramenta, sob uma abordagem investigativa. Por fim, o estudo foi uma oportunidade única de diálogo fora do ambiente acadêmico, que, cumprindo o 
verdadeiro papel da extensão universitária, também transformou a visão de ensino dos pesquisadores envolvidos.

\section{Conceptions of Public School Teachers from Pernambuco about Science Fairs: Reflections based on a Ludic Activity}

\section{ABSTRACT}

This article presents an experience report based on a continuous education event on Science Fairs aimed at teachers from public schools in Pernambuco. The research was elaborated in the form of a participant observation, and had as instrumentation a collective ludic activity, with the objective of examining the conceptions of municipal teachers about Science Fairs. In total, 210 teachers from eight municipalities participated spontaneously in the course. Through discussions around divergent questions present in the group dynamics "Scientific Travel", we sought to understand the conceptions adopted in the planning, organization, monitoring and evaluation of science fair projects. We observed that the majority of teachers prioritize an evaluation of the Fairs based on the construction process of the projects and advocate constant monitoring of the students 'progress even if this partially compromises the participants' autonomy. We identified divergences in the teachers' conceptions regarding their role as expert advisors in the subjects covered at the fairs and also about the criteria for choosing project themes - whether local or more general problems would be prioritized. The study also contributes to contextualize these conceptions from the perspective of teaching by research.

KEYWORDS: Elementary level. Group dynamics. Continuing education. Public education. Investigative teaching.

\section{Agradecimentos}

Agradecemos a todos os professores que participaram dos momentos de convivência e aprendizagem nos cursos de extensão e às Secretarias de Educação do Estado e dos municípios envolvidos. Este projeto foi desenvolvido com os seguintes recursos do Conselho Nacional de Desenvolvimento Científico e Tecnológico (CNPq): Bolsa de produtividade ao primeiro autor, Edital Universal 2016 e Edital 51/2010 (Feiras de Ciências).

\section{Referências}

ANGROSINO, M. V. Etnografia e observação participante. Porto Alegre: Artmed, 2009. ARAÚJO, C. M.; ARAÚJO, E. M.; SILVA, R. D. Para pensar sobre a formação continuada de professores é imprescindível uma teoria crítica de formação humana. Caderno Cedes, Campinas, 
v. 35, n. 95, p. 57-73, 2015. Disponível em https://www.scielo.br/pdf/ccedes/v35n95/0101-3262-ccedes-35-95-00057.pdf. Acesso em 12 jun. 2019

BACHELARD, G. A formação do espírito científico: contribuição para uma Psicanálise

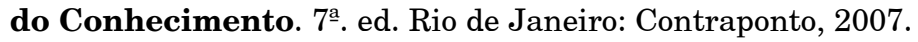

BECK, J.; CZERNIAK, C. M.; LUMPE, A. T. An exploratory study of teachers' beliefs regarding the implementation of constructivism in their classroom. Journal of Science Teacher Education, New Jersey, v. 11, n. 4, p. 323-343, 2000.

CARVALHO, A. M. P. Fundamentos teóricos e metodológicos do ensino por investigação. Revista Brasileira de Pesquisa em Educação em Ciências, v. 18, n. 3, p. 765-794, 2018. Disponível em https://periodicos.ufmg.br/index.php/rbpec/article/view/4852. Acesso em 10 mar. 2019.

DOMÍNGUEZ CHAVIRA, C. T. La lúdica: Una estrategia pedagógica depreciada. Colección Reportes Técnicos de Investigación Serie ICSA, Universidad Autónoma de Ciudad Juárez, Vol. 27, 2005.

FINGER, I.; BEDIN, E. A contextualização e seus impactos nos processos de ensino e aprendizagem da ciência química. Revista Brasileira de Ensino de Ciências e Matemática. v. 2, n. 1, p. 8-24, jan./jul. 2019. Disponível em: <http://seer.upf.br/index.php/rbecm/article/view/9732>. Acesso em: 03 set. 2020

FAGUNDES, T. B. Os conceitos de professor pesquisador e professor reflexivo: perspectivas do trabalho docente. Revista Brasileira de Educação, Campinas, v. 21 n. 65, p. 281-298, 2016.

FARIAS, L. N.; GONÇALVES, T. V. O. Feiras de Ciências como oportunidade de (re)construção do conhecimento pela pesquisa. In.: VIII Encontro Nacional de Pesquisa em Educação em Ciências (VIII ENPEC) e I Congreso Internacional de Investigación en Enseñanza de las Ciencias (I CIEC), Campinas/SP, 2011. Disponível em: <www.nutes.ufrj.br/abrapec/viiienpec/ resumos/R0168-1.pdf>. Acesso em: 04 out. 2016.

GIL-PÉREZ, D.; MONTORO, I. F.; ALÍS, J. C.; CACHAPUZ, A.; PRAIA, J. Para uma imagem não deformada do trabalho científico. Ciência \& Educação, Bauru, v. 7, n. 2, p. 125-153, 2001. Disponível em <https://www.scielo.br/pdf/ciedu/v7n2/01.pdf>. Acesso em 23 abr 2019.

GONÇALVES, A. E. S.; RIBEIRO, M. T. D. Olhares epistemológicos na prática pedagógica de professores de Química. Revista Brasileira de Ensino de Ciências e Matemática. v. 3, n. 1, p. 229-261, jan./jul. 2020. Disponível em: <http://seer.upf.br/index.php/rbecm/article/view/10128>. Acesso em: 03 set. 2020.

GORSE, C. A.; SANDERSON, A. M. Exploring group work dynamics. Em: Boyd, D (Ed.) Anais do 23o. Annual ARCOM Conference, Belfast, Association of Researchers in Construction Management, p. 295-304, 2007.

GRAY, D. E. Pesquisa no Mundo Real. 2a $2^{\text {a }}$ ed., São Paulo: Ed. Penso, 2012.

HERON, J. The Complete Facilitator's Handbook. London: Kogan Page, 1999.

IBGE (2012) Municípios brasileiros. Disponível em <www.ibge.gov.br. Acessado em 13.nov.>.

JIMÉNEZ RAYA, M., LAMB, T. \& VIERA, F. Pedagogy for autonomy in language education in Europe. Towards a framework for learner and teacher development. Dublin: Authentik, 2007.

LEAL, L. A. B.; D’ÁVILA, C. M. A Ludicidade como princípio formativo. Interfaces Científicas - Educação. v. 1, n. 2, p. 41-52, 2013. 
LIMA, K. E. C.; TEIXEIRA, F. M. A atividade experimental como estrutura para o ensino de ciências no CECINE nos anos de 1960 e 1970. ECCOS Revista Científica, n. 45, p. 177-190, 2018.

MUNFORD, D.; LIMA, M. E. C. C. Ensinar ciências por investigação: em que estamos de acordo? Ensaio: Pesquisa em Educação em Ciências, v. 9, n. 1, p. 72-89, 2007. Disponível em https:// www.scielo.br/pdf/epec/v9n1/1983-2117-epec-9-01-00089.pdf. Acesso em 17 nov. 2018.

NASCIMENTO, R. D.; GOMES, A. D. T. A Relação entre o conhecimento conceitual e o desempenho de estudantes em atividades investigativas. Revista Brasileira de Pesquisa em Educação em Ciências. v. 18, n. 3, p. 935-965, 2018.

NOGARO, A.; GRANELLA, E. E. O erro no processo de ensino e aprendizagem. Revista de Ciências Humanas, v. 5, n. 5, p. 31-56, 2004.

OPFER, V. D.; PEDDER, D. Conceptualizing teacher professional learning. Review of Educational Research, v. 81, n. 3, p. 376-407, 2011.

PHILLIPS, P. Professional development as a critical component of continuing teacher quality. Australian Journal of Teacher Education, v. 33, n. 1, p. 37 - 45, 2008. https://files.eric.ed.gov/ fulltext/EJ1069624.pdf. Acesso em 21 jul 2019.

REEVE, J.; JANG, H. What teachers say and do to support students' autonomy during a learning activity. Journal of Educational Psychology, vol. 98, n. 1, p. 209-218, 2006. Disponível em https://selfdeterminationtheory.org/SDT/documents/2006_ReeveJang_JEP.pdf. Acesso 30 jul 2019.

REIS, J. Educação é Investimento. São Paulo: IBRASA, 1968.

RICHARDSON, V. Preservice teachers' beliefs. Em: J. RATHS, \& A. C. MCANINCH (Eds.), Teacher beliefs and classroom performance: The impact of teacher education, volume 6: Advances in teacher education. Greenwich, CT: Information Age. 2003, pp. 1-22.

ROLLNICK, M. et al. The place of subject matter knowledge in pedagogical content knowledge: a case study of South African teachers teaching the amount of substance and chemical equilibrium. International Journal of Science Education, v. 30, n. 10, p. 1365-1387, 2008.

SASSERON, L. H. Alfabetização científica, ensino por investigação e argumentação: relações entre ciências da natureza e escola. Ensaio: Pesquisa em Educação em Ciências, v. 17, n. especial, p. 49-67, 2015.

SILVA, E. L.; PACCA, J. L. A. Algumas implicações do trabalho coletivo na formação continuada de professores. Ensaio: Pesquisa em Educação em Ciências, Belo Horizonte, v. 13, n. 3, p. 3149, dez. 2011. Disponível em <https://www.scielo.br/pdf/epec/v13n3/1983-2117-epec-13-03-00031. pdf>. Acesso em 7 jun 2017.

SWARTZ, R. Mistakes as an important part of the learning process. The High School Journal, vol. 59, n. 6, p. 246-257, 1976.

TARDIF, M. Saberes profissionais dos professores e conhecimentos universitários: Elementos para uma epistemologia da prática profissional dos professores e suas consequências em relação à formação para o magistério. Revista Brasileira de Educação, São Paulo, n. 13, p. 5-24, 2000. Disponível em <http://anped.tempsite.ws/novo_portal/rbe/rbedigital/RBDE13/RBDE13_05_MAURICE_TARDIF.pdf $>$. Acesso em 31 jul 2015.

TORTOP, H. S. Science teachers' views about the science fair at primary education level. Turkish Online Journal of Qualitative Inquiry, v. 4, n. 2, p. 1-8, 2013. 
VALLADARES, L. Os dez mandamentos da observação participante. Revista Brasileira de Ciências Sociais, v. 22, n. 63, p. 153-155, 2007.

VASCONCELOS, S. D.; LIMA, K. E. C. Por que não fazer Feiras de Ciências? Uma análise das dificuldades de professores de escolas públicas municipais em Pernambuco. In: Anais do Encontro Nacional de Ensino de Biologia, Goiânia - GO, 2012. Disponível em meio magnético.

VASCONCELOS, S. D.; SILVA, M. F.; LIMA, K. E. C. Abordagens e procedimentos metodológicos sobre Feiras de Ciências adotados por professores de escolas públicas em um município da Zona da Mata de Pernambuco. Experiências em Ensino de Ciências, v. 10, n. 1, p. 129-140, 2015. Disponível em <http://if.ufmt.br/eenci/artigos/Artigo_ID269/v10_n1_a2015.pdf>. Acesso em 18 set 2017.

WERNECK, V. R. Sobre o processo de construção do conhecimento: o papel do ensino e da pesquisa. Ensaio: Avaliação e Políticas Públicas em Educação, v. 14, n. 51, p. 173-196, 2006. Disponível em <https://www.scielo.br/pdf/ensaio/v14n51/a03v1451.pdf>. Acesso em 13 jan. 2018.

WHYTE, W.F. Sociedade de esquina: a estrutura social de uma área urbana pobre e degradada. Rio de Janeiro, Jorge Zahar, 2005.

ZOMPERO, A. F.; LABURÚ, C. E. Atividades investigativas no ensino de ciências: aspectos históricos e diferentes abordagens. Ensaio: Pesquisa em Educação em Ciências, v. 13, n. 3, p. 67-80, 2011. Disponível em <https://www.scielo.br/pdf/epec/v13n3/1983-2117-epec-13-03-00067. pdf>. Acesso em 4 abr 2016. 